Article

\title{
Management of Municipal Solid Waste in One of the Galapagos Islands
}

\section{Marco Ragazzi ${ }^{1, *}$, Riccardo Catellani ${ }^{1}$, Elena Cristina Rada ${ }^{1,2}$, Vincenzo Torretta ${ }^{2}$ and Xavier Salazar-Valenzuela ${ }^{3,4}$}

1 Department of Civil, Environmental and Mechanical Engineering, University of Trento, Via Mesiano 77, Trento I-38123, Italy; E-Mails: r.catellani@studenti.unitn.it (R.C.); elena.rada@unitn.it (E.C.R.)

2 Department of Biotechnologies and Life Sciences, University of Insubria, Via G.B. Vico 46, Varese I-21100, Italy; E-Mail: vincenzo.torretta@uninsubria.it

3 Office of Environmental Management, Municipality of Santa Cruz, Av. Charles Darwin y 12 de Febrero, Puerto Ayora 200350, Santa Cruz Island, Galapagos, Ecuador; E-Mail: xasalazar@uce.edu.ec

4 Central University of Ecuador, Galapagos Head, Barrio Miraflores entre Petrel y San Cristóbal, Puerto Ayora 200350, Santa Cruz Island, Galapagos, Ecuador

* Authors to whom correspondence should be addressed; E-Mail: marco.ragazzi@unitn.it; Tel.: +39-0461-282609; Fax: +39-0461-282672.

External Editor: Marc A. Rosen

Received: 6 October 2014; in revised form: 24 November 2014 / Accepted: 26 November 2014 / Published: 9 December 2014

\begin{abstract}
This paper analyses some aspects of the management of municipal solid waste in one of the islands of the Galapagos archipelago. The aim is to point out a few aspects of an interesting experience that could help decision managers faced with the organization of the waste sector in similar realities. The relevance of this case study consists in the presence of a very famous National Park surrounding the inhabited area. The role of tourism in the generation of waste is analyzed too.
\end{abstract}

Keywords: Galapagos; island; municipal solid waste; tourism 


\section{Introduction}

This paper relates to a study conducted on the island of Santa Cruz, Galápagos Archipelago, Ecuador. Given its exceptional and unique biodiversity, the archipelago enjoys special protection and laws. The total land area is 788,200 square kilometers, of which $96.7 \%$ consists of the National Park, and the remaining 3.3\% is made up of urban and agricultural areas, located on the islands of San Cristobal, Santa Cruz, Isabela and Floreana. The entire province can be approximately divided into three strongly interconnected subsystems: a green park, a marine reserve and urban agglomerates [1].

In recent decades, the existences of a local population and increasing flow of tourists and heavy development have produced the first signs of the potential unsustainability of this fragile ecosystem. The national 2010 census reported a total population of 21,067 inhabitants, of whom 17,997 were in urban areas and the remaining 3070 were in rural areas. Population growth is one of the major emerging issues, resulting from tourism dynamics and the consequent increase in waste production [2-5].

Over the years, numerous measures have been proposed to address the problems related to the sustainable disposal of municipal solid waste (MSW). A curbside collection system has been recently established, together with a center for sorting and recycling [2].

The aim of this work is to analyze the criticalities arising from the need to preserve the ecosystems of this extraordinary island and the need to find an economically and technologically sustainable model of MSW management for the municipality of Santa Cruz, similarly to what is done in other low income countries [6-10]. A specific aim concerns the finding of replicable solutions for the management of MSW in tourist islands.

Our study focuses also on the new neighborhood under construction in Puerto Ayora in accordance with national legislation the Millennium Development Goals, national legislation, including the Law of the Special Regime for the Conservation and Sustainable Development of the Province of Galapagos, the Plan of Conservation and Sustainable Development developed by the former Instituto Nacional Galápagos (INGALA), and following the suggestions of the Pan American Health Organization [11-13].

\section{Methodology}

The present work has been developed through the following steps:

- Collection of literature data specifically available for the island of Santa Cruz

- Planning of field activity for the verification of the available data and their integration/updating

- Organisation and development of a 2 month stay of one of the authors for the planned field activities

- Critical analysis of the collected data, also for pointing out replicable experiences

- Elaboration of proposals for the improvement of the waste management

\section{Characteristics of the Area of Study}

The island of Santa Cruz is the second largest island $\left(986 \mathrm{~km}^{2}\right)$ of the archipelago, with a maximum altitude of 864 meters above sea level and with the largest population in the province. The district of Santa Cruz includes the capital Puerto Ayora and the villages of Bellavista and Santa Rosa. In addition to the island of Baltra (site of the airport), the islands of Marchena, Pinta, Pinzon, Seymour and other smaller islets are under the jurisdiction of this district. 
The population of the island has increased considerably: in 2010 the population reached 15,393 inhabitants, of whom 11,974 residents were in the urban area of Puerto Ayora, 2425 in Bellavista and 994 in Santa Rosa. The population density of Puerto Ayora is the largest of the entire island. In fact, $84.1 \%$ of the population is concentrated in this town distributed over an area of about 190 ha, with an average population density of 3.36 people per household [14]. The town of Puerto Ayora is divided into five sectors.

The municipality has decided to further expand the urbanized area, because the existing one is no longer sufficient to accommodate future population growth. For that reason the new neighborhood El Mirador was planned [13]. The project involves the construction of 1130 lots with a rectangular shape of $15 \mathrm{~m} \times 20 \mathrm{~m}$. The lots are grouped into sub districts (manzanas) with about 66 batches each, within which there is often an area of $1500 \mathrm{~m}^{2}$ for recreational space. Public facilities are also provided in the center of the neighborhood to serve the community such as a sports field, a church, a medical clinic, and a children's playground.

The municipality has proposed certain types of homes that can be built. There are restrictions on the maximum number of buildings, density, and land use, the materials that can be used and on the heights of the fences. In El Mirador it is forbidden to open activities that could disturb the inhabitants such as bars, pubs, clubs, woodworking shops, machine shops, car washes, boat workshops and other potentially noisy or polluting activities [15]. The housing capacity of the new district includes 10,000 units [15], however using the current value of the inhabitants/dwelling (rounded up) a more appropriate value of just over 6000 inhabitants has been decided. Another 250 police officers and 100 soldiers, who will be transferred to the Mirador, need to be added, by moving two small barracks.

The collection of MSW of the few homes already inhabited is done "on call".

\section{Current Waste Management}

Throughout the district there is a service for the collection of MSW covering the whole of Puerto Ayora and the other two residential areas on the island. Where this service is not offered, people bury their own waste. The collection system (Figure 1) provides for the separation of different categories of material at source, leaving the user to divide the material into recyclable, organic and non-recyclable material (Figure 2). For hospitals and clinics a collection of "hospital" waste is provided.

Until 2009 there was not a technological landfill on the island and the waste was spread in a place $27 \mathrm{~km}$ away on the road to Baltra. To mitigate the pollution of this area, since 2011 there has been land reclamation and a real landfill is being built.

In the canton of Santa Cruz, MSW incineration (open burning) is carried out by very few citizens who are sensitive to the criticalities of this issue. This is a very positive aspect of the behavior of the local population. 
Figure 1. Comparison of municipal solid waste (MSW) disposal methods by the population of the Province of Galapagos, and those for the population of Santa Cruz [16] (1 = Municipal service; 2 = Abandonment on roads, rivers, soil; 3 = Incineration; 4 = Recycling/landfilling; $5=$ Other).

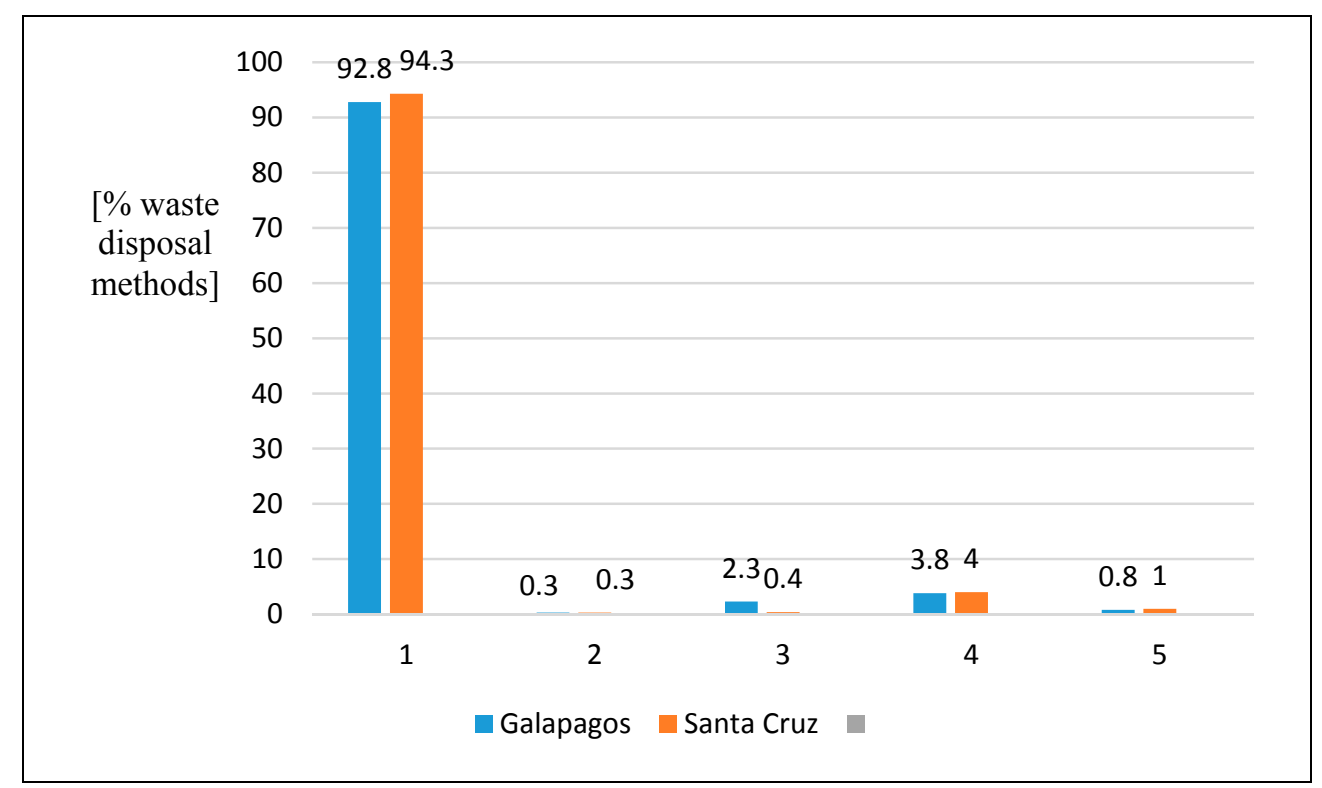

\subsection{MSW Collection}

The cleaning of streets, gardens, parks and other communal areas is carried out once a week on the busiest streets, every day in the commercial areas located in the south of the city, twice a week in the residential areas, and twice a month in the peripheral area in the north of the city.

Solid waste is collected by three compactor trucks and two trucks with wooden boxes. Two teams are used to collect waste, performing on average two trips to the designated disposal/recovery, picking up approximately 10.5 tons of waste per day.

The waste collected as non-recyclable (residual MSW) and organic waste not suitable for composting are sent to the landfill site. The construction of the new landfill gave the possibility to manage them in a more organized way. Occasionally the scrap metal is taken away by private traders.

The curbside collection provides each user with three $70 \mathrm{~L}$ bins, for organic, recyclable and non-recyclable waste, respectively. Hospitals and private clinics are expected to collect medical waste in special bags, which are picked up by a specialist equipped with protective equipment and a specially equipped closed box.

The recyclable waste and organic bins are delivered three times per week to Valverde Environmental Park, which is located about $4 \mathrm{~km}$ from the town on the road to Bellavista. The recyclable waste is separated manually and treated in order to retrieve the greatest possible amount, while the organic waste is started at the stage of shredding and biostabilization.

For the street waste collection, there are delivery points which are normally equipped with bins for plastic, paper and organic waste. In the most crowded places of the city, there may also be even larger bins for the collection of recyclable and of not recyclable materials.

The overall waste collection is described in Figure 2. 
Figure 2. Waste collected with the current system.

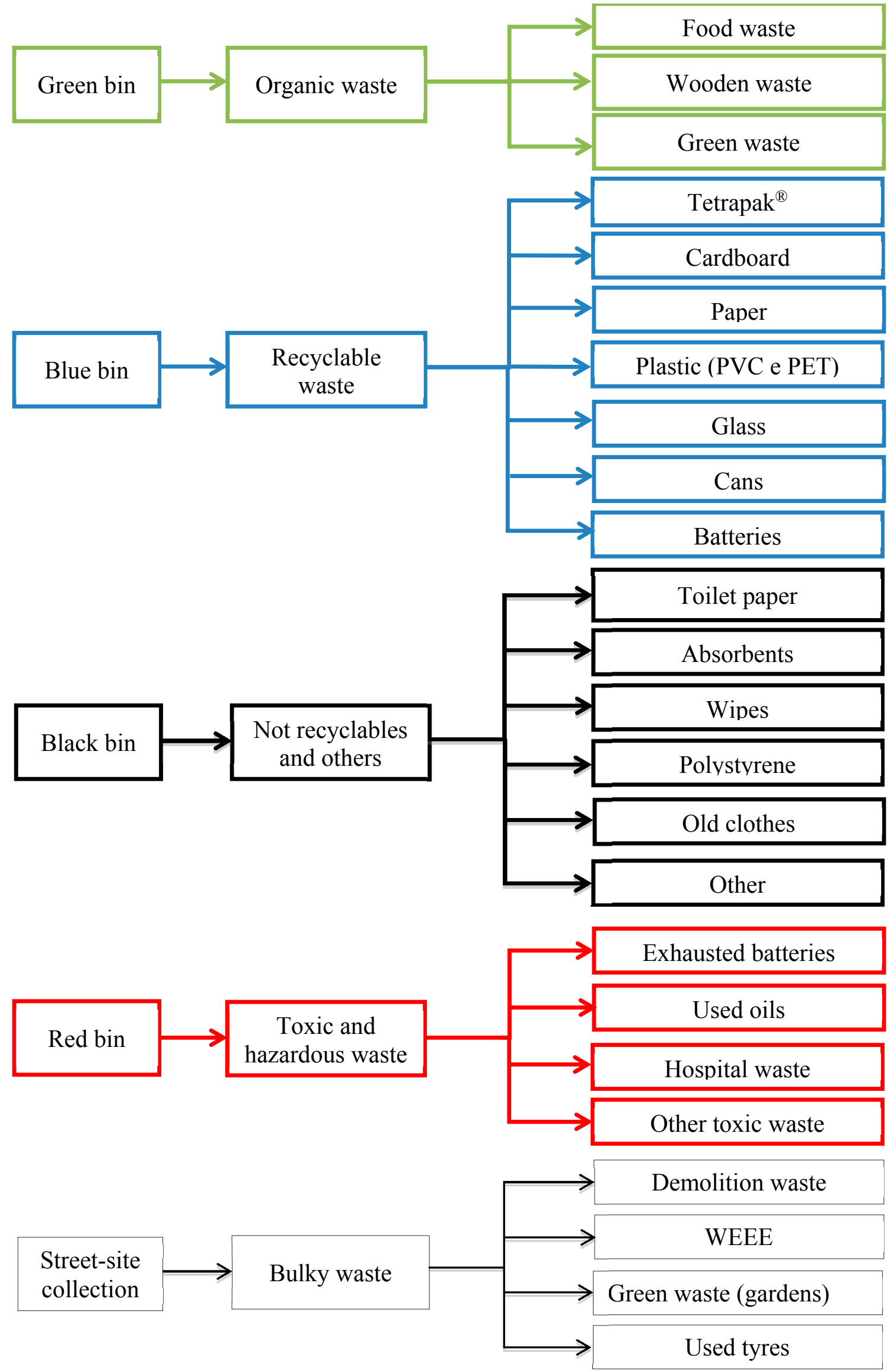




\subsubsection{Organic Waste}

The organic waste, which is collected separately in green bins, is treated in a bio-stabilization plant and subsequently sent to a composting process. After the treatment, it is sieved and packed in $20 \mathrm{~kg}$ bags to be sold or stored. The municipality mainly uses this compost as fertilizer for flowerbeds and green spaces.

The average daily organic waste treated from 2009-2011, when this method developed quickly, was 1.98 tons/day. In Figure 3 the monthly values are reported.

Figure 3. Organic waste collection from 2009 until 2011 [16].

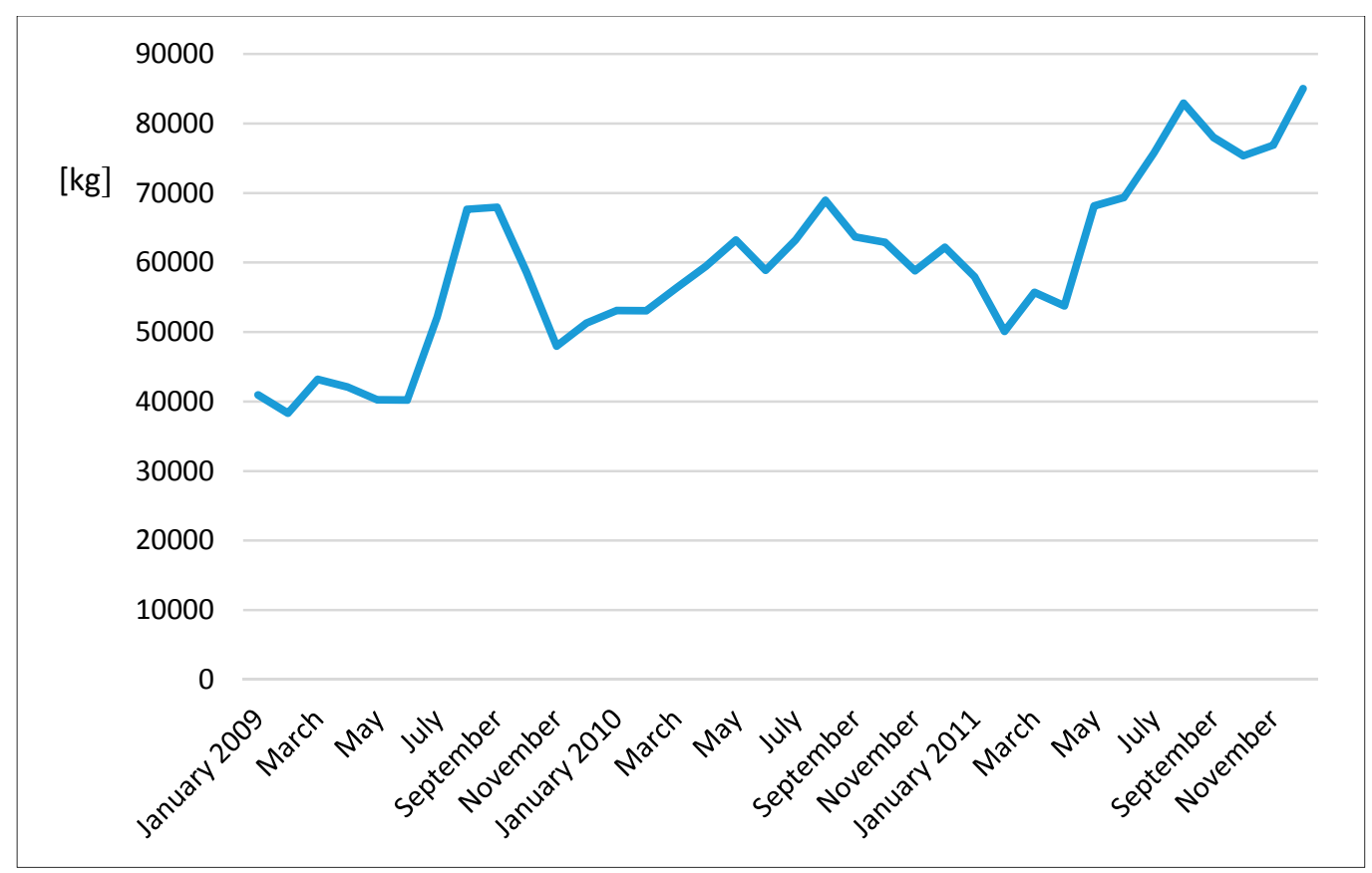

\subsubsection{Recyclable Waste}

The recyclables collected are transferred to the Valverde recycling center where they are manually separated into various product fractions. The average daily quantity of separated waste treated is 1.47 tons. Details are reported in Table 1.

\subsubsection{Residual MSW}

An average yield of 7.4 tons per day of residual MSW (that is non-recyclable waste and recyclable materials not source separated) is delivered to the landfill $27 \mathrm{~km}$ away [17]. In Figure 4 the monthly values are reported.

With this latest data, averaged over a time window of three years, it can be concluded that the organic fraction is about $18 \%$ of the treated waste, waste collected as recyclable is about $14 \%$, while residual MSW accounts for approximately $68 \%$ of the total. By adding the two recoverable fractions, it is possible to reach $32 \%$ of recyclable material collected, which, in a context such as Ecuador, is certainly encouraging. 
Table 1. Recyclable materials, separated in the Valverde waste recycling center between 2009 and 2011 [16].

\begin{tabular}{|c|c|c|c|c|c|c|c|c|c|c|c|}
\hline & Month & $\begin{array}{c}\text { Cardboard } \\
(\mathrm{kg})\end{array}$ & Glass (kg) & $\begin{array}{c}\text { Plastic } \\
(\mathrm{kg})\end{array}$ & Paper (kg) & $\begin{array}{c}\text { Tetrapack }^{\circledR} \\
(\mathbf{k g})\end{array}$ & Cans (kg) & $\begin{array}{c}\text { Packaging for } \\
\text { Eggs (kg) }\end{array}$ & $\begin{array}{c}\text { Batteries } \\
(\mathrm{kg})\end{array}$ & $\begin{array}{c}\text { Cement Bags } \\
(\mathrm{kg})\end{array}$ & $\begin{array}{c}\text { Total } \\
\text { (kg) }\end{array}$ \\
\hline \multirow{12}{*}{2009} & January & 20,050 & 13,360 & 5121 & 2608 & 206 & 109 & 119.4 & 100 & 452 & 42,127 \\
\hline & February & 18,389 & 9,560 & 3845 & 1453 & 267 & 636 & 343.2 & 0 & 1609.2 & 36,102 \\
\hline & March & 14,055 & 14,135 & 5855 & 3709 & 437 & 226 & 91.4 & 0 & 689 & 39,197 \\
\hline & April & 15,557 & 13,172 & 7738 & 3948 & 292 & 490 & 375.6 & 0 & 616 & 42,188 \\
\hline & May & 18,295 & 15,336 & 5764 & 2823 & 270 & 430 & 232.8 & 0 & 596 & 43,747 \\
\hline & June & 18,800 & 13,451 & 4920 & 2994 & 373 & 412 & 363 & 0 & 585 & 41,898 \\
\hline & July & 22,379 & 14,721 & 4805 & 3050 & 526 & 559 & 368.6 & 0 & 936 & 47,344 \\
\hline & August & 21,425 & 13,085 & 5347 & 2964 & 980 & 1025 & 932.6 & 0 & 623 & 46,380 \\
\hline & September & 19,198 & 11,924 & 7169 & 4215 & 887 & 849 & 755.2 & 0 & 525 & 45,522 \\
\hline & October & 15,663 & 9144 & 4489 & 3258 & 442 & 561 & 338 & 0 & 1132 & 35,029 \\
\hline & November & 19,932 & 10,620 & 4930 & 2838 & 818 & 402 & 0 & 0 & 713 & 40,253 \\
\hline & December & 21,256 & 11,250 & 4951 & 4089 & 531 & 756 & 0 & 0 & 695 & 43,527 \\
\hline \multirow{12}{*}{2010} & January & 21,099 & 14,345 & 4947 & 3774 & 885 & 1068 & 0 & 0 & 376 & 46,494 \\
\hline & February & 20,254 & 11,177 & 5471 & 4562 & 873 & 612 & 0 & 0 & 427 & 43,376 \\
\hline & March & 19,728 & 15,512 & 6314 & 6409 & 858 & 1099 & 0 & 0 & 204 & 50,124 \\
\hline & April & 18,975 & 13,846 & 7659 & 4227 & 1004 & 512 & 0 & 0 & 1160 & 47,384 \\
\hline & May & 19,193 & 12,594 & 5987 & 3676 & 861 & 496 & 0 & 0 & 455 & 43,262 \\
\hline & June & 17,638 & 11,505 & 6127 & 3845 & 1204 & 384 & 0 & 1209 & 1245 & 431,577 \\
\hline & July & 18,959 & 13,107 & 5523 & 3795 & 959 & 187 & 0 & 0 & 728 & 43,257 \\
\hline & August & 17,414 & 12,995 & 5416 & 5001 & 1037 & 225 & 0 & 0 & 636 & 42,724 \\
\hline & September & 17,917 & 14,120 & 5255 & 3224 & 733 & 341 & 0 & 0 & 668 & 42,259 \\
\hline & October & 17,440 & 13,170 & 4563 & 3142 & 807 & 376 & 0 & 0 & 1372 & 40,871 \\
\hline & November & 19,868 & 14,137 & 5160 & 3103 & 1708 & 277 & 0 & 0 & 480 & 44,732 \\
\hline & December & 24,578 & 15,132 & 4349 & 3619 & 764 & 346 & 0 & 0 & 584 & 49,373 \\
\hline
\end{tabular}


Table 1. Cont.

\begin{tabular}{|c|c|c|c|c|c|c|c|c|c|c|c|}
\hline & Month & $\begin{array}{c}\text { Cardboard } \\
(\mathrm{kg})\end{array}$ & Glass (kg) & $\begin{array}{c}\text { Plastic } \\
(\mathrm{kg})\end{array}$ & Paper (kg) & $\begin{array}{c}\text { Tetrapack }^{\circledR} \\
(\mathbf{k g})\end{array}$ & Cans (kg) & $\begin{array}{c}\text { Packaging for } \\
\text { Eggs (kg) }\end{array}$ & $\begin{array}{c}\text { Batteries } \\
(\mathbf{k g})\end{array}$ & $\begin{array}{c}\text { Cement Bags } \\
(\mathrm{kg})\end{array}$ & $\begin{array}{c}\text { Total } \\
(\mathrm{kg})\end{array}$ \\
\hline \multirow{12}{*}{2011} & January & 18,757 & 13,790 & 4737 & 6581 & 0 & 610 & 0 & 0 & 1286 & 45,761 \\
\hline & February & 15,973 & 13,864 & 7194 & 4175 & 0 & 346 & 0 & 0 & 0 & 41,552 \\
\hline & March & 17,621 & 17,041 & 6345 & 4388 & 0 & 709 & 0 & 0 & 0 & 46,103 \\
\hline & April & 20,604 & 15,665 & 6264 & 4666 & 0 & 348 & 0 & 0 & 166 & 47,714 \\
\hline & May & 19,577 & 15,156 & 6253 & 3614 & 0 & 287 & 0 & 0 & 338 & 45,225 \\
\hline & June & 19,648 & 14,167 & 5404 & 4073 & 0 & 678 & 0 & 0 & 408 & 44,377 \\
\hline & July & 19,686 & 14,660 & 7331 & 4723 & 0 & 814 & 0 & 0 & 611 & 47,825 \\
\hline & August & 18,620 & 12,741 & 6190 & 3862 & 0 & 490 & 0 & 368 & 713 & 42,984 \\
\hline & September & 19,165 & 12,084 & 5564 & 3112 & 0 & 450 & 0 & 0 & 364 & 40,739 \\
\hline & October & 18,513 & 13,578 & 4880 & 3074 & 0 & 490 & 0 & 0 & 792 & 41,327 \\
\hline & November & 18,707 & 15,755 & 6027 & 4210 & 0 & 385 & 0 & 0 & 960 & 46,044 \\
\hline & December & 21,398 & 17,556 & 7209 & 4850 & 0 & 460 & 0 & 0 & 1100 & 52,573 \\
\hline
\end{tabular}


Figure 4. Residual MSW collection from 2009 until 2011 [16].

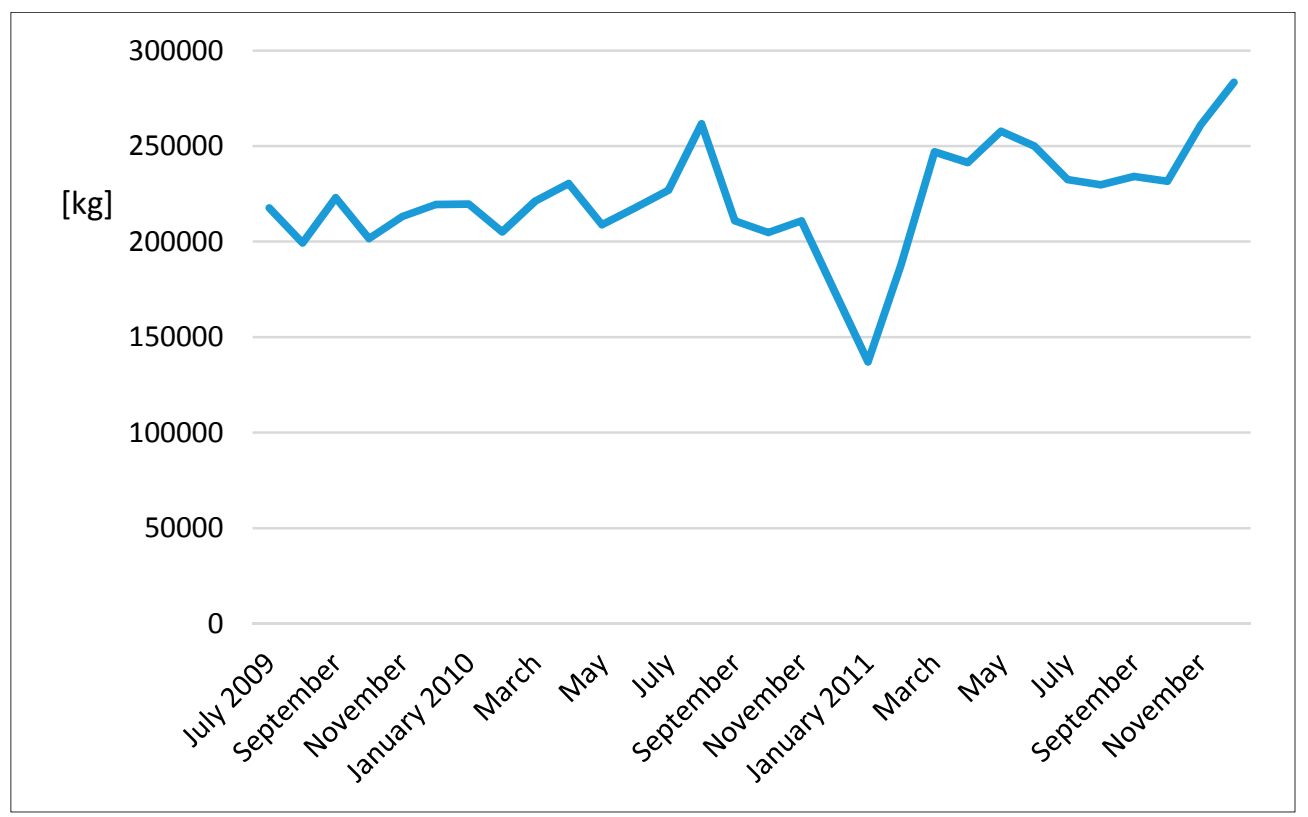

\subsection{Waste Management in Puerto Ayora}

\subsubsection{Waste Produced}

In 2008, a study was carried out on the construction and safety of the landfill $27 \mathrm{~km}$ on behalf of the WWF. This study [18] showed that the most representative fractions of waste in MSW produced by the residents of Puerto Ayora and tourism are: kitchen organic waste, glass, cardboard and plastic bags (Table 2). Such significant data regarding packaging are not surprising, in fact, the archipelago is located very far from the mainland, and consequently the goods need more protection during transportation regardless of the means used. Plastic bags and diapers are two categories that commonly appear in the waste produced by residents.

Table 2. MSW flux in Puerto Ayora [18].

\begin{tabular}{cc}
\hline MSW Flux & Quantity (kg/inh/day) \\
\hline Residual MSW & 0.476 \\
Source separated recyclable waste & 0.14 \\
Green waste from gardens & 0.139 \\
Municipal market and slaughterhouse waste & 0.02 \\
Total in Puerto Ayora & 0.775 \\
\hline
\end{tabular}

The percentage of food waste is relevant in the present MSW (Table 3).

A projection of the amount of waste produced per capita until 2028 was estimated. The Table 4 shows the results of the study [18]. The role of organic fraction is expected to change in percentage; its absolute value $(\mathrm{kg} / \mathrm{inh} /$ day) in Puerto Ayora is affected by the restriction to the import of fresh fruits from the continent: indeed fruit beverages must be prepared only from packed juices; more in general, any contamination with external seeds must be avoided. That reduces the per-capita generation of food waste compared to conventional cases. 
Table 3. Types of waste in Puerto Ayora [17].

\begin{tabular}{ccccc}
\hline Fraction & $\begin{array}{c}\text { Residential Area } \\
\mathbf{( \% )}\end{array}$ & $\begin{array}{c}\text { Intermediate Area } \\
\mathbf{( \% )}\end{array}$ & $\begin{array}{c}\text { Commercial Area } \\
\mathbf{( \% )}\end{array}$ & $\begin{array}{c}\text { Average } \\
\mathbf{( \% )}\end{array}$ \\
\hline Food waste & 49.00 & 43.77 & 27.83 & 40.20 \\
Other waste & 26.08 & 27.14 & 26.36 & 26.53 \\
Glass & 5.31 & 1.69 & 18.39 & 8.46 \\
Cardboard & 2.98 & 4.79 & 13.10 & 6.96 \\
Diapers & 4.95 & 8.37 & 0.98 & 4.77 \\
Plastic bags & 2.07 & 2.99 & 4.67 & 3.24 \\
PET & 1.30 & 1.40 & 2.79 & 1.83 \\
Green waste from gardens & 2.72 & 1.79 & 0.00 & 1.50 \\
Textile waste & 1.43 & 2.79 & 0.23 & 1.48 \\
Paper & 0.93 & 1.34 & 1.88 & 1.38 \\
Tetrapack & 0.71 & 1.69 & 0.83 & 1.08 \\
High density plastics & 0.97 & 1.00 & 1.06 & 1.01 \\
Scrap metal & 1.17 & 0.64 & 0.83 & 0.88 \\
Batteries & 0.00 & 0.00 & 0.90 & 0.30 \\
Shoes & 0.26 & 0.50 & 0.00 & 0.25 \\
Trays & 0.00 & 0.00 & 0,15 & 0.05 \\
Polystyrene foam & 0.06 & 0.10 & 0.00 & 0.05 \\
Copper wires & 0.06 & 0.00 & 0.00 & 0.02 \\
\hline
\end{tabular}

Table 4. Waste generation: future expectation [18].

\begin{tabular}{cc}
\hline Flux & $\begin{array}{c}\text { MSW Production expected in 2028 } \\
(\mathbf{k g} / \mathbf{i n h} / \mathbf{d a y})\end{array}$ \\
\hline Food waste & 0.211 \\
Residual MSW & 0.315 \\
Recyclable waste & 0.155 \\
Green waste from gardens & 0.154 \\
Market and slaughterhouse waste & 0.022 \\
\hline
\end{tabular}

\subsubsection{MSW Management}

Plastic bags are also used for waste before depositing them in recycle bins. In the stream of source separated recyclable waste and residual MSW, plastic bags are not a problem, because in the former they are separated manually and in the latter they are taken directly to the landfill. However, organic waste needs to be carefully removed to avoid contamination of the final product.

The waste from the municipal slaughterhouse, the public market and the fish cleaning and packing firm are dumped in the landfill. Waste from demolition and scrap from the building industry have the same fate.

An effort must be made for improving the management of tires, used batteries and a part of green waste, but this can be seen as a demonstration that the optimization of waste management is obtainable through a pathway of years. 
Paper, cardboard, scrap metal, paper packaging bags of cement and plastic are separated manually and safely by operators equipped with individual protection systems. After being compressed and packaged, the waste is sent to the mainland and sold as shown in Table 5.

Table 5. Gain from sale of recyclable material [18].

\begin{tabular}{cc}
\hline Material & Gain (US\$/ton) \\
\hline Glass & 60 \\
Plastic & 150 \\
Paper & 120 \\
Scrap metal & 260 \\
\hline
\end{tabular}

Recently, the separation of waste from electrical and electronic equipment (WEEE) has also begun, which is packed and sent to the mainland, and which costs around US\$ 300/ton for disposal. Cells and batteries are separated from the recyclable waste stream, and at the moment are stored under a shed awaiting a suitable place for disposal [18].

For a certain period, a small incinerator was operating for the disposal of hospital waste. A discussion was opened about the acceptability of combustion in this context. An alternative approach based on the autoclave principle was presented a few years ago as an alternative.

\section{Potential Improvements of the Waste Management}

The above described situation refers to a 3 year period when the management of waste in the island showed significant improvements. In this chapter, potential improvements to be considered for additional modifications are discussed.

\subsection{Co-Composting of Organic and Green Waste from Gardens}

An interesting alternative for the disposal of sewage sludge is to co-compost it with organic waste from the MSW from households, restaurants, hotels, markets and garden waste.

Numerous experiments have been carried out [19,20] on co-composting two or more streams of organic matter. The combination of sewage or faecal sludge/organic fraction of MSW is the most commonly studied, because the combined treatment of this waste would result in considerable savings compared to separate management. In addition, these waste streams can be processed very well together because they are complementary. Organic waste is particularly rich in organic carbon [21], while faecal sludge has a good content of nitrogen and moisture, the fundamental parameters for the successful outcome of the end product.

The characteristics of the output product are strongly affected by the quality of the incoming products and the techniques used for composting. Wastes from pruning, grass cuttings and leaves are the most valuable fractions in the co-composting process [22]. The high $\mathrm{C} / \mathrm{N}$ ratio makes it advisable to compost waste containing a high concentration of nitrogen as sewage sludge.

Normally you try to get at least one sewage sludge sedimentation or dry fixed bed dehumidification. This pre-treatment is essential to maintain a mixing ratio of faecal sludge $v s$. organic matter of MSW as close as possible to $0.25-0.5$, however up to 0.1 [23] is also possible in the case of untreated sludge. 
Faecal sludge can be co-composted with any type of biodegradable material. Drying beds could help its management. It is advisable to leave the mature compost for 90 days in order to have a better product and it is hygienic to turn the piles over every 10 days. Given the variability of the water content of the input material, it is necessary to change the ratios of mixture so that the moisture of the material to be composted is maintained in the range of optimal values equal to $50 \%-60 \%$ [19].

The municipality should also have a shredder to reduce the volume of incoming waste, green waste, especially from gardens. After shredding, mixing could take place in the bioreactor which is already owned by the Valverde recycling center.

This technique avoids the need to burn plant cuttings. Once this process has been started, we suggest cleaning the area where, to date, this waste (and often also non organic waste) is burned. Larger logs of wood, not for grinding, can be recovered for other uses (i.e., boat building, furniture or other objects).

One of the problems encountered in the treated and sieved material, is the pieces of plastic bags that are used to contain the organic household waste. A good initiative by the Galapagos National Park (GNP) and the Galapagos Government Council might be to ban plastic shopping bags and use envelopes made of biodegradable or recycled paper. Further progress could be made by banning imports of disposable plastic (such as dishes and cutlery).

The economic sustainability of a composting plant also depends on the revenues from the sales of compost. The current process did not guarantee a high quality product, but the above suggested practices should ensure an increase in the fertilizing properties of this product.

In recent years, politicians in Ecuador have worked hard to develop a more responsible model of organic farming towards small farmers and the environment. The integral agrarian reform introduces the concept of food sovereignty, and encourages people to produce food mainly for their own consumption, avoiding the use of chemical agents and methods of cultivation which over time can damage the soil. Increasing the quality and production of the organic fertilizer produced in this process appears to be consistent with the guidelines of the central state.

According to studies [17], in the future $0.387 \mathrm{~kg} / \mathrm{inh} /$ day of compostable material will be produced, while the production of dried sludge in the neighborhood El Mirador is estimated to be equal to $0.043 \mathrm{~kg} / \mathrm{inh} /$ day. Considering a 2036 population of 19,516 inhabitants in Puerto Ayora and 6021 for the new expansion, an estimated production of compostable waste amounts to 3607.2 tons/year whilst for treated sludge a 94.6 tons/year is expected. The small quantity of the latter fraction of the total allows for easy dilution during composting.

Summing up, the above mentioned measures aimed to co-composting could help in decreasing the impact of the management of biodegradable fractions.

\subsection{Waste Batteries}

Ecuador has no specialized facilities for the recovery and treatment of waste batteries. The product fractions separated in the sorting center also include exhausted batteries. For now, these are stored in bins under a shed in the Valverde recycling center, pending the setting up of a place where they can be permanently placed. Alternatively, one of the four tanks intended for the ashes of hospital waste has also been considered, because the tanks are considered as sufficiently safe. 
By placing two rows of bins full of batteries, would be able to form inside the tank two levels of drums, to be sealed to prevent leakage. Each tank is $3 \mathrm{~m} \times 2 \mathrm{~m}$ in plan and $1.5 \mathrm{~m}$ in height, and could hold 48 cans filled with two rows of 24, plus another row of bins with a maximum height of $40 \mathrm{~cm}$.

To increase the security, a row could be divided with the other planks of wood recovered from the collection and use as a barrier and stabilizer for the drums of batteries.

It would be good practice to encourage the use of rechargeable AA batteries and a mini stylus in order to decrease the production of exhausted batteries. An effective information campaign could also be addressed to tourists to take home the exhausted batteries.

These measures could help in decreasing the amount of heavy metals not correctly managed.

\subsection{Waste Containing Asbestos}

In a recent census, of the 4270 buildings examined in Puero Ayora, the roofs of 3549 buildings were covered as follows:

- 1303 concrete (slabs, cement);

- 1210 asbestos cement (Eternit ${ }^{\circledR}$, Eurolit $\left.^{\circledR}\right)$;

- 1032 zinc;

- 4 other materials.

About one third are asbestos cement coverings, known under the trade names of Eternit ${ }^{\circledR}$ or Eurolit ${ }^{\circledR}$. In the case of the asbestos roofs, the risks depend on the probability of releasing asbestos fibers into the air and/or in the soil, which in turn is linked to the state of preservation of the product itself. Where in the surrounding parts of the asbestos roof, fiber dispersion occurs, the removal, encapsulation or constructing above the roof, covering it may be required. Asbestos should be removed by a highly skilled labor force in order to ensure maximum security for the reclamation and disposal of roofing elements containing asbestos. To proceed with the necessary checks on the state of conservation of the asbestos cement roofing and possible safe disposal, appropriate technical training is recommended.

In Ecuador, a moratorium is proposed to prohibit imports from the mainland of this type of product. Moreover, the island does not have a proper system for the removal and final disposal of this material.

\subsection{MSW Management in the New Urbanized Area in El Mirador}

The new urbanization will be served by the same curbside collection system that already exists. It is recommended that an interior space in each lot is acquired, which is easily accessible from the outside area, to place the bins for the collection of recyclable, non-recyclable and organic materials.

One of the problems most often encountered in the streets of Puerto Ayora is that green waste is left in the streets. It is therefore necessary to obtain a clearance of at least $8 \mathrm{~m}^{2}$, protected with a fence or a gate, where the population is allowed to dispose of the garden and green waste separately with those in small demolitions and tires. These small ecological islands should be installed in each sub-lot (in total 21) or preferably in the free areas in the middle or in those small free areas that are occasionally found near the sidewalks.

In this way, the entire neighborhood would be fully serviced by facilities with a catchment area with a radius of approximately $120 \mathrm{~m}$ and a population of a little more than 230 people. Both the radius and 
number of people are reasonably low and make it possible to improve the collection of these MSW fractions, as long as the storage areas are emptied three times a week as currently happens for curbside collection in the town.

\subsection{Other Recommendations}

It is important that decisions are taken with regard to the reduction of waste. For example, a campaign may be useful to sensitize employees to the reduction of printed paper or at least to reuse the printed paper for rough copies of documents.

Many of the privately owned gardens are full of unused and discarded objects. The municipalities could introduce a law for the protection of public decorum to facilitate the disposal of this waste. For example, a monthly market for citizens could be held to exchange and barter certain goods.

The cleaning and maintenance of roads could be probably not sufficient to guarantee an optimal service for the city. Incentives for the creation of groups of volunteers to help the municipal workers might help give citizens a strong sense of collaboration. These organizations could promote artistic recycling courses to involve more and more citizens in the fight against waste and the uncontrolled production of MSW.

\section{Conclusions}

The study enabled us to build a picture of the waste management in the study area, highlighting the positive experiences and suggesting some improvements.

Concerning the positive experiences in the area, it must be pointed out that the collection of mixed packaging coupled with a manual selection plant should be taken into account for a replication in similar realities where the tourist fluxes increase this king of waste fractions.

A more careful waste management would transform the operations that are normally considered to be problematic, ensuring a better quality of the organic waste and recyclables separation by a more careful collection. In addition, actions have been outlined for the appropriate disposal of hazardous and non-hazardous municipal waste, aimed at safeguarding the environment in line with the principles of sustainable development.

In our opinion, this study can be a useful approach to address similar problems everywhere, with particular attention to the low income countries and oceanic islands.

\section{Acknowledgments}

The authors would like to acknowledge the Municipality of Santa Cruz for its efforts in the management of waste and the data provided. We also like to acknowledge World Wildlife Fund and Toyota for their financial support to the waste management system in Santa Cruz Island.

\section{Author Contributions}

Marco Ragazzi and Elena Cristina Rada designed the research; Riccardo Catellani performed the research and preliminary analyzed the data under the local supervision of Xavier Salazar-Valenzuela; 
Vincenzo Torretta wrote the paper. All authors contributed to a deeper data analysis, read and approved the final manuscript.

\section{Conflicts of Interest}

The authors declare no conflict of interest.

\section{References}

1. Charles Darwin Research Station (CDRS); Parque Nacional Galapagos (PNG). Galápagos Report 2009-2010. Puerto Ayora, Ecuador. Available online: http://www.galapagospark.org/ oneimage.php?page=ciencia (accessed on 3 September 2014).

2. Gobierno Autónomo Descentralizado Municipal de Santa Cruz. Diagnóstico sistema asentamientos humanos (Diagnosis Human Settlement System). Puerto Ayora, Ecuador. Available online: http://www.gobiernogalapagos.gob.ec/wp-content/uploads/downloads/2013/08/PDOT-Santa-Cruz2012_2_segundo1.pdf (accessed on 3 September 2014).

3. Parque Nacional Galapagos (PNG). Control and eradication of introduced animals. Puerto Ayora, Ecuador. Available online: http://www.galapagospark.org/nophprg.php?page=parque_nacional_ introducidas_animales (accessed on 3 September 2014).

4. Parque Nacional Galapagos (PNG). Control and eradication of introduced plants. Puerto Ayora, Ecuador. Available online: http://www.galapagospark.org/nophprg.php?page=parque_nacional_ introducidas_plantas (accessed on 3 September 2014).

5. Watkins, G.; Cruz, F. Galapagos at Risk-A Socioeconomic Analysis; Charles Darwin Foundation: Puerto Ayora, Ecuador, 2007.

6. Collivignarelli, C.; de Felice, V.; Di Bella, V.; Sorlini, S.; Torretta, V.; Vaccari, M. Assessment of sanitary infrastructures and polluting loads in Pojuca river (Brazil). Water Pract. Technol. 2012, 7 , doi:10.2166/wpt.2012.044.

7. Torretta, V.; Conti, F.; Leonardi, M.; Ruggieri, G. Energy recovery from sludges and sustainable development: A Tanzanian case study. Sustainability 2012, 4, 2661-2672.

8. Vaccari, M.; Torretta, V.; Collivignarelli, C. Effect of improving environmental sustainability in developing countries by upgrading solid waste management techniques: A case study. Sustainability 2012, 4, 2852-2861.

9. Rada, E.C.; Ragazzi, M.; Fedrizzi, P. WEB-GIS oriented system viability for municipal solid waste selective collection optimization in developed and transient economies. Waste Manag. 2013, 33, 785-992.

10. Rada, E.C.; Zatelli, C.; Mattolin P. Municipal solid waste selective collection and tourism. WIT Trans. Ecol. Environ. 2014, 180, 187-197.

11. Environmental Ministry of Ecuador. Texto Unificado de Legislación Ambiental (Environmental regulation). Available online: http://www.google.it/url?sa=t\&rct=j\&q=\&esrc $=$ s\&source=web\&cd= $1 \&$ ved $=0 \mathrm{CCIQFjAA} \&$ url $=\mathrm{http} \% 3 \mathrm{~A} \% 2 \mathrm{~F} \% 2 \mathrm{Fwww}$.miliarium.com $\% 2 \mathrm{Fpaginas} \% 2 \mathrm{Fleyes} \% 2 \mathrm{Finter}$ nacional\%2FEcuador\%2FGeneral\%2FTextoUnificado\%2FLibroVI-Anexo1.doc\&ei=119AUPijM8r4QSiZw\&usg=AFQjCNEJzwhh8zfH3q_YsRiQUZ (accessed on 3 September 2014). 
12. Organization of the Petroleum Exporting Countries (OPEC). OPEC Annual Statistical Bulletin 2012. Available online: http://www.opec.org/opec_web/static_files_project/media/downloads/ publications/ASB2012.pdf (accessed on 3 September 2014).

13. United Nations (UN). The Millenium Development Goals. Available online: http://www.un.org/ millenniumgoals/bkgd.shtml (accessed on 3 September 2014).

14. Instituto Nacional de Estatisticas y Censos (INEC). Censo de poblacion y vivienda 2011 (Census of Population and Housing 2011). Quito, Ecuador. Available online: http://www.ecuadorencifras.gob.ec/ (accessed on 3 September 2014).

15. Gobierno Autónomo Descentralizado Municipal de Santa Cruz. Proyecto de "Urbanizacion El Mirador" en terrenos y el Gobierno Municipal de Santa Cruz (Project of urbanization "El Mirador" in the Municipal Government of Santa Cruz); Santa Cruz Municipality: Puerto Ayora, Ecuador, 2010.

16. Instituto Nacional de Estatisticas y Censos (INEC). Encuesta de condiciones de vida en Galapagos 2009-2010; Report on Life Conditions in Galapagos; Quito, Ecuador, ye. Available online: http://www.ecuadorencifras.gob.ec/ (accessed on 3 September 2014).

17. De la Torre, F. Relleno Sanitario para la Isla Santa Cruz, Provincia de Galápagos (Characterization of solid waste in the Islands Santa Cruz, San Cristobal and Isabela, Galapagos); Municipality of Santa Cruz, Office of Environmental Managment: Puerto Ayora, Ecuador, 2009.

18. Plan de manejo de desechos para las Islas Galapagos (Waste Management Plan for Galapagos Islands); World Wildlife Fund (WWF): Quito, Ecuador, 2010.

19. Cofie, O.; Kone, D.; Rothenberger, S.; Moser, D.; Zubruegg, C. Co-composting of faecal sludge and organic solid waste for agriculture: Process dynamics. Water Res. 2009, 43, 4665-4675.

20. Rada, E.C.; Ragazzi, M.; Villotti, S.; Torretta, V. Sewage sludge drying by energy recovery from OFMSW composting: Preliminary feasibility evaluation. Waste Manag. 2014, 34, 859-866.

21. Andreottola, G.; Ragazzi, M.; Foladori, P.; Villa, R.; Langone, M.; Rada, E.C. The unit integrated approach for OFMSW. UPB Sci. Bull. 2012, 74, 19-26.

22. Bikovens, O.; Dizhbite, T.; Telysheva, G. Characterization of humic substrances formed during co-composting of grass and wood wastes with animal grease. Environ. Technol. 2012, 33, 1427-1433.

23. Eawag/Sandec - Department of Water and Sanitation for Developing Countries. Faecal Sludge Management-Sandec Training Tool, Module 5; Doulaye Konè \& Sylvie Peter: Dubendorf, Switzerland, 2008.

(C) 2014 by the authors; licensee MDPI, Basel, Switzerland. This article is an open access article distributed under the terms and conditions of the Creative Commons Attribution license (http://creativecommons.org/licenses/by/4.0/). 